\title{
Effects of High Hydrostatic Pressure on Physicochemical Properties of Waxy Rice Starch
}

\author{
${ }^{\dagger}$ Soo-Jeong Lee \\ Dept. of Food \& Nutrition, Bucheon University, Bucheon 420-735, Korea
}

고압처리 찹쌀전분의 이화학적 특성

${ }^{\dagger}$ 이 수 정

부천대학 식품영양과

국문요약

찹쌀전분의 고압처리시 $\mathrm{pH} 3 \sim 10$ 조건에서 고유점도는 $1.328 \sim 1.426 \mathrm{ml} / \mathrm{g}$ 범위로 원료전분 $(1.15 \mathrm{~m} \ell / \mathrm{g})$ 보다 낮았다. 특히, 고유점도는 산성 및 알칼리성 조건에서 감소하였다. 전분의 호화과정 중 열에너지 량을 나타내는 호화엔탈피는 $\mathrm{pH} \mathrm{3,4}$ 및 5 조건에서 고압처리한 찹쌀전분이 각각 $13.86,13.47$ 및 $13.42 \mathrm{~J} / \mathrm{g}$ 으로 원료전분 $(16.3 \mathrm{~J} / \mathrm{g})$ 보다 낮은 값을 보였다. 찹쌀전분의 호화온도 및 엔탈피 감소는 고유점도가 낮아지는 현상과 일치하였다.

Key words: high hydrostatic pressure, physicochemical properties, waxy rice starch, intrinsic viscosity, differential scanning calorimetry

\section{INTRODUCTION}

Starch is the main constituent of grains, which is generally between 60 and $75 \%$ of the weight of the grain and provides $70-80 \%$ of the calories consumed by humans worldwide. Due to its unique functional properties, it is widely used in industrial and food applications (Thomas \& Atwell 1997; Parker \& Ring 2001). However, native starch needs to be modified to develop desirable functional properties, such as solubility, texture, adhesion and heat tolerance (Ronald CD 1998). Starch modification can be accomplished through derivatization (etherification, esterification, cross-linking and grafting of starch), decomposition (acid or enzymatic hydrolysis and oxidation of starch) or physical treatment of starch using heat, pressure and moisture.

Chemical modification involves the introduction of functional groups into the starch molecule, resulting in markedly altered physic-chemical properties (Cha et al. 2007; Choi \& Kerr 2003;
Kim et al. 1999). Extreme treatments (temperature and pressure) can be used as physical modification techniques that gelatinized the starch (Katleen et al. 2009). Pressurization produces unique properties that are different from those of heat-gelatinization, where heat-treatment destroys starch granules, resulting in a transparent solution, but pressure-treatment swells the granules, while maintaining the granular structure (Hayashi \& Hayashida 1989). The potential application of high pressure for food processing and preservation has been investigated with growing interest by various researchers as an alternative to traditional heat treatment procedures (Fonberg-Broczek et al. 2005; Knorr et al. 2006; Hendrickx et al. 1998). This technology has several advantages over heat treatment, including better retention of nutritional and functional ingredients in the processed product. High pressure also makes it possible to produce foods with novel textures (Stolt et al. 2001). High pressure affects only secondary and tertiary bonds, which means only large molecules, cell membranes,

\footnotetext{
${ }^{\dagger}$ Corresponding author: Soo-Jeong Lee, Dept. of Food \& Nutrition, Bucheon University, Bucheon 420-735, Korea. Tel: $+82-$ 32-610-3445, Fax: +82-32-610-3205, E-mail: gerda@bc.ac.kr
} 
enzymes etc. are denatured. However, primary or covalent bonds are not affected. This means that low molecular weight quality determining components like vitamins, pigments, flavor substances as well as their precursor, which are highly affected by the traditional thermal processing, remain intact. A pressure of $600 \mathrm{MPa}$ applied to starch granules could deteriorate their structure depending on the water content (Mercier et al. 1968). Meanwhile, a lower pressure $300 \mathrm{MPa}$ applied together with acid and heat was shown to cause fast depolymerization of starch (Kim \& Hamdy 1987).

In the case of high pressure application of starch, most previous studies attempted to achieve gelatinization at pressures greater than $300 \mathrm{MPa}$. Thus, the effect of lower high pressure $(100 \mathrm{MPa})$ on evaluated to expand the potential applications of this technology. The objective of this study was to evaluate the effect of HHP treatment on the rheological properties of WRSs and to evalute the potential of using HHP for obtaining starchbased ingredients with novel texture characteristics.

\section{MATERIALS AND METHODS}

\section{Waxy Rice Starch}

Waxy rice starch (WRS, Indica) was purchased from Bangkok Starch Industrial Co.(Nakornprathom, Thailand). All other chemicals used were of analytical grade.

\section{High Hydrostatic Pressure (HHP) Treatment}

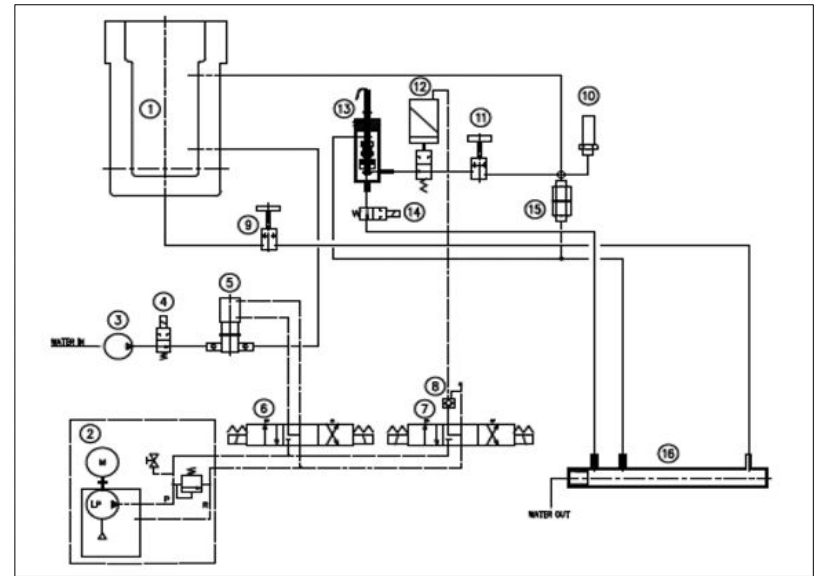

Fig. 1. Schematic diagram of the HHP apparatus. (1) vessel, (2) oil return system, (3) pump, (4) solenoid value, (5) booster pump, (6) solenoid value, (7) solenoid value, (8) pilot check, (9) drain value, (10) safety sensor, (11) relief value, (12) solenoid value, (13) level sensor, (14) solenoid v-alue, (15) safety value, (16) drain pipe.-
Fifty $\mathrm{g}$ of WRS was suspended in $50 \mathrm{~m} \ell$ of distilled water, and the $\mathrm{pH}$ of waxy rice starch was adjusted from 3 to 10 using $0.5 \mathrm{~N} \mathrm{HCl}$ and $0.5 \mathrm{~N} \mathrm{NaOH}$. After $\mathrm{pH}$ adjustment, waxy rice starch suspensions were vacuum-packed in polyethylene bags $(150 \times 250 \mathrm{~mm})$. Packed samples were subjected to the vessel unit of the HHP apparatus (UHP machine TFS-2L, Toyo Koatsu., Hiroshima, Japan). The HHP apparatus consists of cylindrical chamber of $12 \mathrm{~cm}$ (diameter) $\times 20 \mathrm{~cm}$ (height), hydrostatic pump, pressure controller and process control system (Fig. 1). The samples were treated at a pressure $100 \mathrm{MPa}$ for $24 \mathrm{hr}$. The temperature of the vessel unit was thermostatically controlled at $30{ }^{\circ} \mathrm{C}$ throughout treatment. The WRS treated under HHP was neutralized and then centrifuged by high speed centrifugation at $3,000 \times \mathrm{g}$ for $20 \mathrm{~min}$. The starch cake was washed 3 times with distilled water and centrifuged again, and then freeze dried.

\section{Intrinsic Viscosity}

WRSs were dissolved (0.2-0.28\%) in dimethyl sulfoxide (DMSO), held at $100^{\circ} \mathrm{C}$ for $4 \mathrm{~min}$, and then filtered through a $0.45 \mathrm{~mm}$ Millipore filter. The viscosity of the solutions was measured using a Cannon-Fenske capillary viscometer (size 100; Cannon Instrument Co., State College, PA, USA) at $25^{\circ} \mathrm{C}$. Prior to measurement, the solution was placed for $30 \mathrm{~min}$ in a $25^{\circ} \mathrm{C}$ water bath to equilibrate the temperature. Specific viscosity ( $\eta$ $\mathrm{sp})$ and intrinsic viscosity ([ $\eta])$ were determined as follows:

$$
\begin{gathered}
\eta \mathrm{sp}=(\eta-\eta \mathrm{s}) / \eta \mathrm{s} \text { and }[\eta]=\lim _{\mathrm{c} \rightarrow 0} \eta \mathrm{sp} / \mathrm{C} \\
\text {. }
\end{gathered}
$$

where $\eta$ is the solution viscosity, $\eta \mathrm{s}$ is the solvent viscosity, and $\mathrm{C}$ is the solution concentration.

\section{Differential Scanning Calorimetry (DSC)}

The DSC characteristics were measured using a DSC-7 (PerkinElmer, Waltham, MA, USA). Starch samples (16 mg) were weighed in a large volume stainless steel pan and then distilled water (48 mg) was added. The pan was hermetically sealed and heated at a heating rate of $10^{\circ} \mathrm{C} / \mathrm{min}$ and a heating range of 25 to $120^{\circ} \mathrm{C}$. An empty pan was used as a reference. The DSC thermogram was analyzed using the Thermal Analysis Pyris Software interfaced with the DSC. The $\triangle \mathrm{H}$ and $\triangle \mathrm{T}$ values were evaluated from the peak area and the onset point of the endothermic peak of gelatinization at about $60^{\circ} \mathrm{C}$, respectively. 


\section{RESULTS AND DISCUSSION}

\section{Intrinsic Viscosity of HHP Treated WRSs}

The intrinsic viscosity values of WRSs at different $\mathrm{pH}$ values aand HHP treatments are listed in Table 1.

The intrinsic viscosity of HHP treated WRSs ranged from 1.328 to $1.426 \mathrm{~m} / \mathrm{g}$ and depended on the $\mathrm{pH}$ conditions (3 to 10). These value were lower than the intrinsic viscosity of native waxy rice starch $(1.15 \mathrm{~m} / \mathrm{g})$. The intrinsic viscosities decreased at acidic or alkaline $\mathrm{pH}$. It is well known that hydroxonium ions $\left(\mathrm{H}_{3} \mathrm{O}^{+}\right)$attack glycosidic oxygen atoms and hydrolyse the glycidic linkages during the process of acid thinning. Acid gradually degrades the surface of the starch granule first before entering the inner region.

According to Shon et al. (2005), the rice starch dispersions in a dimethyl sulfoxide (DMSO) solution displayed rheological behaviors similar to those of weak gels. The viscosity of starch pastes changed depending on the $\mathrm{pH}$ due to the addition of

Table 1. Intrinsic viscosity of native and HHP treated waxy rice starches

\begin{tabular}{lc}
\hline \hline \multicolumn{1}{c}{ Starch samples } & Intrinsic viscosity $(\mathrm{m} \ell / \mathrm{g})$ \\
\hline Native & $1.56 \pm 0.11^{1)}$ \\
$\mathrm{HHP}^{2)}$ treated at $\mathrm{pH}$ & $1.353 \pm 0.14$ \\
$\mathrm{HHP}$ treated at $\mathrm{pH} 4$ & $1.426 \pm 0.16$ \\
$\mathrm{HHP}$ treated at $\mathrm{pH} 5$ & $1.328 \pm 0.12$ \\
$\mathrm{HHP}$ treated at $\mathrm{pH} 6$ & $1.397 \pm 0.13$ \\
$\mathrm{HHP}$ treated at $\mathrm{pH} 7$ & $1.408 \pm 0.11$ \\
$\mathrm{HHP}$ treated at $\mathrm{pH} 8$ & $1.354 \pm 0.17$ \\
$\mathrm{HHP}$ treated at $\mathrm{pH} 9$ & $1.332 \pm 0.15$ \\
$\mathrm{HHP}$ treated at $\mathrm{pH} 10$ & $1.357 \pm 0.13$
\end{tabular}

1) All values are mean \pm S.D. of 3 replicates,

2) HHP means high hydrostatic pressure. various sour substances (citric acid, acetic acid, lactic acid, malic acid, tartaric acid and ascorbic acid) to corn starch pastes. The hydrolysis of amylose and a small amount of sour substances caused amylose and amylopectin chains to leach out, which led to an increase in viscosity (Hirashima et al. 2005).

On the other hand, the intrinsic viscosity of acid thinned starch under high pressure following a combination of acid thinning and high pressure treatment in 1 to 3 passes decreased as much as the viscosity acid thinned the starch for $1 \mathrm{hr}$ or acid starch for $2 \mathrm{hr}$.

This result shows that the combination of acid thinning and high pressure might be effective for preparing modified starches. According to Stute et al. (1993), most starches display very little swelling and maintain their own granular character such as that observed after heat gelatinization under high pressure treatment. Under high pressure, the pressure acts immediately and independent of the size and the shape of the product, and does not break covalent bonds (Thevelein et al. 1981).

Normally, the intrinsic viscosity is correlated to the molecular weight or size of the material being analyzed. No significant differences were observed between the effect of pressure and $\mathrm{pH}$ on WRS (100 MPa and $\mathrm{pH} 3-10)$. A pressure of $100 \mathrm{MPa}$ was not sufficient to produce structural changes and therefore, further studies are needed to investigate the disintegration of the granular structure of WRS under the extent pressure-induced condition. Typical type of intrinsic viscosities of WRSs were shown in Fig. 2.

\section{DSC Characteristics}

The onset temperature and gelatinization enthalpy of native starch and WRSs were listed in Table 2. The onset temperature shifted to lower values in WRSs HHP treated at $\mathrm{pH} 3$ to 5 when compared to that in native starch but increased slightly with an increase in $\mathrm{pH}$ from 8 to 10 . Gelatinization enthalpy, which
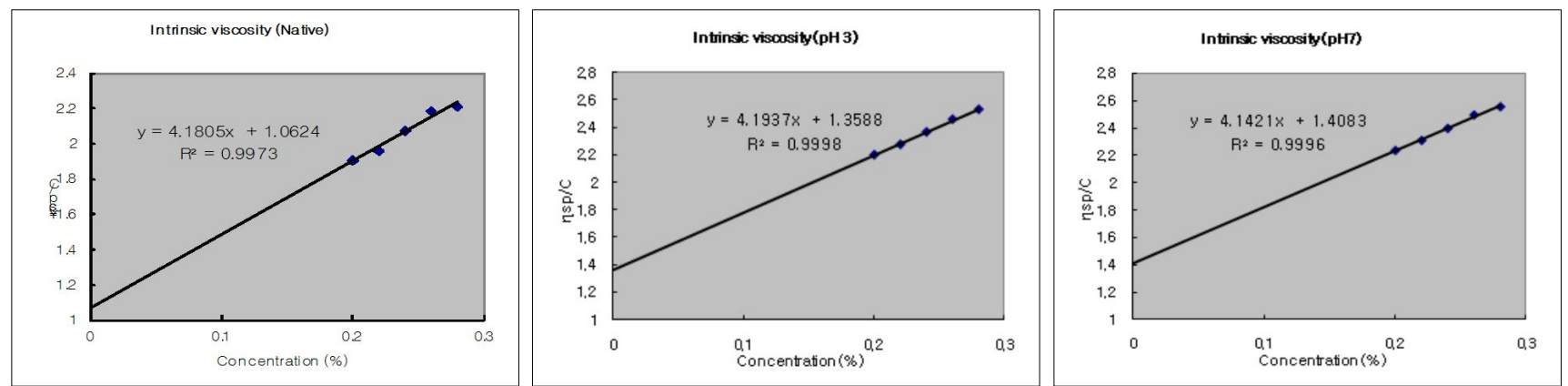

Fig. 2. Intrinsic viscosities of WRS at $\mathrm{pH} 3, \mathrm{pH} 7$ and nature WRS. 
Table 2. DSC characteristics of native and HHP treated waxy rice starches

\begin{tabular}{|c|c|c|c|}
\hline \multirow[b]{2}{*}{ Starch samples } & \multicolumn{3}{|c|}{ DSC characteristics } \\
\hline & $\begin{array}{l}\text { Peak temp. } \\
\left({ }^{\circ} \mathrm{C}\right)\end{array}$ & $\begin{array}{l}\text { Onset } \\
\left({ }^{\circ} \mathrm{C}\right)\end{array}$ & $\begin{array}{c}\text { Enthalpy } \\
(\mathrm{J} / \mathrm{g})\end{array}$ \\
\hline Native & $68.67 \pm 0.13^{1)}$ & $65.28 \pm 0.26$ & $16.31 \pm 0.63$ \\
\hline $\mathrm{HHP}^{2)}$ treated at $\mathrm{pH} 3$ & $77.94 \pm 0.21$ & $59.83 \pm 0.19$ & $13.86 \pm 0.33$ \\
\hline HHP treated at $\mathrm{pH} 4$ & $77.66 \pm 0.37$ & $59.72 \pm 0.28$ & $13.47 \pm 0.86$ \\
\hline HHP treated at $\mathrm{pH} 5$ & $77.87 \pm 0.35$ & $59.78 \pm 0.16$ & $13.42 \pm 0.23$ \\
\hline HHP treated at $\mathrm{pH} 6$ & $78.31 \pm 0.11$ & $59.73 \pm 0.08$ & $14.73 \pm 0.63$ \\
\hline HHP treated at $\mathrm{pH} 7$ & $77.75 \pm 0.25$ & $59.86 \pm 0.16$ & $14.16 \pm 0.53$ \\
\hline HHP treated at $\mathrm{pH} 8$ & $77.69 \pm 0.18$ & $59.68 \pm 0.11$ & $14.23 \pm 0.20$ \\
\hline HHP treated at $\mathrm{pH} 9$ & $77.86 \pm 0.44$ & $59.78 \pm 0.26$ & $14.24 \pm 0.33$ \\
\hline HHP treated at $\mathrm{pH} 10$ & $78.18 \pm 0.31$ & $59.95 \pm 0.28$ & $14.49 \pm 0.85$ \\
\hline
\end{tabular}

1) All values are mean \pm S.D. of 3 replicates,

2) HHP means high hydrostatic pressure.

represents the amount of thermal energy involved in the gelatinization process, was reduced from $16.3 \mathrm{~J} / \mathrm{g}$ in native starch to 13.86, 13.47, and $13.42 \mathrm{~J} / \mathrm{g}$ in WRSs treated at $\mathrm{pH} \mathrm{3,4}$ and 5, respectively. The onset temperature and gelatinization enthalpy of WRSs under HHP were generally lower than that of native starch (Table 2).

Acid thinning treatment under high pressure was more effective at reducing both the onset temperature and the gelatinization enthalpy of starch. Because of this direct relationship between double helix content and crystallinity, it is thought that leaching of the amorphous region by acid hydrolysis increases starch crystallization and consequently increases both the gelatinization temperature and enthalpy. Enthalpy might be involved in the cleavage of hydrogen bonds and other associative bonding forces among starch molecules, and such bonds must be limited by oxidation and acetylation. This accounts for the reduction of enthalpy following chemical modification (Lawal OS 2004). The decrease in gelatinization temperature and enthalpy are in agreement with the intrinsic viscosity values. Typical DSC thermograms of WRSs were shown in Fig. 3.

\section{CONCLUSION}

A pressure of $100 \mathrm{MPa}$ was not sufficient to produce structural changes and therefore, further studies are needed to investigate the disintegration of the granular structure of WRS under extent pressure-induced condition. In addition, the result will be

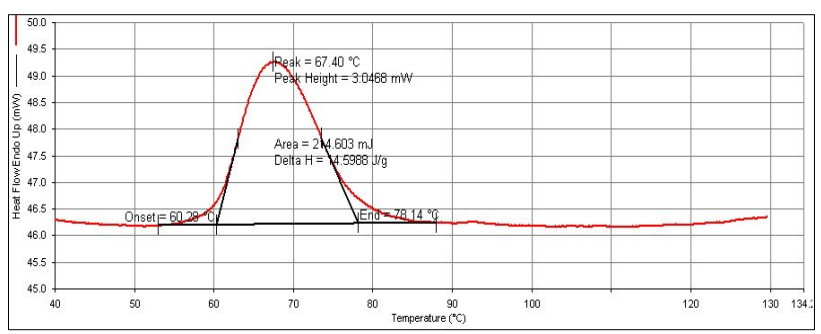

Native

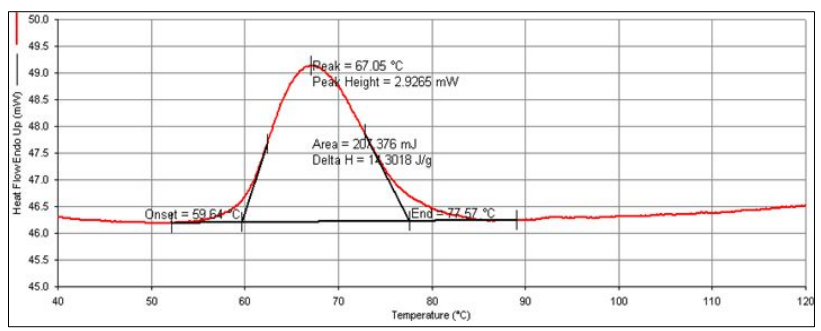

pH 3

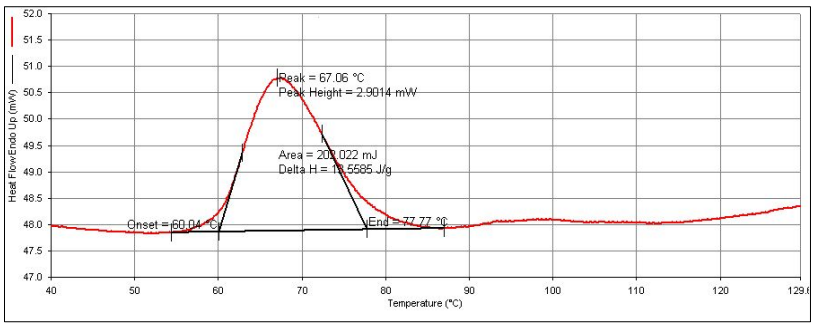

$\mathrm{pH} 7$

Fig. 3. DSC thermograms of native waxy rice starch and waxy rice starches which were HHP treated at 100 MPa for 24 hr.

applicable for further study of starch modification including microfluidization to assess the value of using physical processing and to develop a fundamental understanding of the relationship between the structure and function of the treated starches.

\section{ACKNOWLEDGEMENTS}

This work was supported by 2010 Bucheon University faculty research grant.

\section{REFERENCES}

Cha JY, Choi AJ, Chun BY, Kim MJ, Chun HS, Kim CJ, Cho YJ, Kim CT. 2007. Physicochemical characteristics of acid thinned and high pressure treated waxy rice starch for Yukwa (Korean rice snack) production. Food Sci Biotech 16:943947

Choi SD, Kerr WK. 2003. Effect of chemical modification of 
wheat starch on molecular mobility as studied by pulsed 1HNMR. Lebensm Wiss U Technol 36:105-112

Fonberg-Broczek M, Windyga B, Szczawiński J, Szczawińska, M, Pietrzak D, Prestamo G. 2005. High pressure processing for food safety. Acta Biochimica Polonica 52:721-724

Hayashi R, Hayashida A. 1989. Increased amylase digestibility of pressure-treated starch. Agric Biol Chem 53:2543-2544

Hendrickx M, Ludikhuyze L, Van den Broeck I, Weemaes C. 1998. Effects of high pressure on enzymes related to food quality. Trends in Food Sci Tech 9:197-203

Hirashima M, Takahashi R, Nishinari K. 2005. Effects of adding acids before and after gelatinization on the viscoelasticity of cornstarch pastes. Food Hydrocolloids 19:909-914

Kim K, Hamdy MK. 1987. Depolymerization of starch by high pressure extrusion. Food Sci 52:1387-1390

Kim CT, Shih FF, Champagne ET, Daigle K. 1999. Effects of phosphoylating salts and temperature on the preparation of rice starch phosphates by extrusion. Starch 51:280-286

Knorr D, Heinz V, Buckow R. 2006. High pressure application for food biopolymers. Biochimica et Biophysica Acta 1764: 619-631

Lawal OS. 2004. Composition, physicochemical properties and retrogradation characteristics of native, oxidized, acetylated and acid-thinned new cocoyam(Xanthosama sagittifolium) starch. Food Chem 87:205-218

Mercier C, Charbonniere R, Guilbot A. 1968. Influence d'un traitement par pression sur la structure granulaire de differents amidons et sur leur sensibilite aux enzymes. Starch 20:6-11

Parker R, Ring SG. 2001. Aspects of physical chemistry of starch. Cereal Sci 34:1-17

Ronald CD. 1998. The New Starches. pp. 34-56. Food Product Design

Shon KJ, Lim ST, Yoo B. 2005. Rheological properties of rice starch dispersions in dimethyl sulfoxide. Starch 57:353-369

Stolt M, Oinonen S, Autio K 2001. Effect of high pressure on the physical properties of barley starch. Innovative Food Sci Emerging Technologies 1:167-175

Stute R, Klingler RW, Boguslawski S, Eshtiaghi MN, Knorr D. 1993. Effects of high pressures treatment on starches. Starch 48:399-408

Thevelein JK, Van Assche JA, Heremans K, Gerlsma SY. 1981. Gelatinisation temperature of starch, as influenced by high pressure. Carbohydrate Research 93:304-307

Thomas DJ, Atwell WA. 1997. Starch Structure. pp. 1-12. Starches in American Association of Cereal Chemists, Eagan Press

접 수 : 2011년 10월 11일
최종수정 : 2011년 11월 28일
채 택 : 2011년 12월 7일

